\title{
PRESS RELEASES
}

\section{Groatian Institute of Immunology: where have things got stuck?}

\author{
Anto Bajo, PhD, Institute of Public Finance, Zagreb \\ MARKO PRIMORAC, PHD, Facilty of Economics and Business, Zagreb
}

\begin{abstract}
The public is faced with a lot of contradictory information and dilemmas about the status of the Institute of Immunology in the government finance system. The Institute's financial position is unclear, as are arguments for its privatisation or possible reasons for staying in state ownership. This analysis is aimed at briefly clarifying the Institute's financial position and examining the justifiability of its privatisation vs. remaining in the state's portfolio.
\end{abstract}

The Institute is a joint stock company that needs to be restructured, recapitalised or privatised. The Institute of Immunology is a joint stock company engaged in the production, import and distribution of vaccines under Croatia's Mandatory Vaccination Programme. It is the only Croatian producer of immunobiological preparations, operating as a joint stock company in state ownership. Pursuant to the Government's Decision on establishing a list of companies and other legal entities of strategic and special interest to the Republic of Croatia (OG 94/2OI3), the Company has been classified under companies of special interest which need restructuring, recapitalisation or (full or partial) privatisation.

Privatisation of the Institute. The state owned $73.4 \%$ of the Institute's equity capital in 20I4. As a result of the Company's long-standing financial problems, in April 20I4, the Government issued a decision on its privatisation, and in January 2015, a Decision on the initial price and implementation of the public tendering procedure for the purchase of 157,997 shares (54.4\% of equity) of the Company. After the sale of part of its stake ( $9.5 \%$ of equity), the Croatian Health Insurance Institute should retain its control package of shares (a minimum of $25 \%+$ I share). The second Public Call for Binding Tenders was published in 20I4. During the first call for (non-binding) tenders, eight letters of intent were received, with only one binding offer submitted by 25 March 2015 (that of the counselling company Visia Croatica Ltd). . The pharmaceutical companies have withdrawn their offers, because a potential investor is required to invest a minimum of HRK Ioom in the construction of a new facility to ensure obtaining a permanent production license, retaining production in the country and producing blood derivatives exclusively from locally collected plasma.

The Institute's financial position is extremely weak. The Institute has operated at a loss ever since 2010 (in 2OI4, it stood at HRK 2I.Im). Total liabilities were high (HRK I25.6m in 2OI4, of which liabilities to banks and other financial institutions accounted for HRK 44m) (Tables 2 and 4). No company would be able to operate with such annual losses and liabilities. While long-term debt predominated with $69 \%$,

${ }^{\mathrm{I}}$ It is noteworthy, however, that four sets of bid documents were purchased during the call for binding tenders for the purchase of the shares, at a price of HRK I5,OOO (three of them from foreign pharmaceutical companies and one from a counselling company Ltd). 
short-term liabilities grew rapidly. Total revenues dropped from HRK 92m in 2010 to about HRK $20 \mathrm{~m}$ in 2014 (Table I). Expenditures also decreased in the said period, but at a slower pace (from HRK IO4.5m to HRK 4Im), as did operating expenses, from HRK $97.7 \mathrm{~m}$ to $34.9 \mathrm{~m}$ (see Table 6). Within operating expenses, material expenses and staff expenses dropped markedly (from HRK 49.Im to HRK 9.6m and from HRK $32.6 \mathrm{~m}$ to HRK $17.3 \mathrm{~m}$ respectively).

Liabilities grow while assets shrink. Long-term liabilities (mainly those to banks) went up from HRK I7.9m in 2010 to HRK 6I.3m in 20I2. The Company's total liabilities exceeded equity by 50\% in 2014. Financial expenses (mainly interest expenses) rose from HRK $6.8 \mathrm{~m}$ in 2010 to HRK 9.7m in 2013 (up 43\%). After 20I2, the Institute's long-term financial liabilities to banks and other financial institutions have decreased. However, this is not due to debt repayment, but due to the conversion of long-term debt into short-term debt (short-term liabilities to banks went up from HRK I.9m in 2012 to HRK I3.7m in 20I4).

The value of assets decreased sharply, from HRK $255 \mathrm{~m}$ in 2010 to HRK 2O2m in 2OI4. This was due to reductions in the values of: short-term assets (mainly inventories), from HRK 44.Im to HRK 27.6m; short-term receivables, from HRK $17.5 \mathrm{~m}$ to HRK 4.7m; and cash at bank and on hand, from HRK 20.2m to just slightly over HRK 250,000. The average receivables collection period increased from 70 days in 2010 to 95 days in 2014 (Table 5), whereas at the same time, the average liabilities settlement period increased from 375 to I,O5O days.

Insolvency accompanied by reduced activity and profitability. Almost $60 \%$ of the Institute's short-term liabilities in 2014 were intended for long-term asset financing, which is not desirable. The poor liquidity situation is further reflected in the cash-to-short-term-debt ratio which is almost equal to zero. The most liquid assets (cash) are currently sufficient to cover only a small share of short-term liabilities. Business activity is weak. The total asset and current asset turnover ratios, as well as the inventories and receivables turnover ratios have deteriorated markedly. Profitability indicators: gross and net profit margins, as well as return on assets (ROA) and return on equity (ROE) are negative. All the ratios confirm that the Institute's continued operation is seriously threatened.

The Institute is insolvent and is facing bankruptcy. The extent to which the state can and is allowed to financially support it is questionable (primarily due to the EU competition regulations). It is also debatable whether taxpayers are willing to okay the Government's spending over HRK Ioom on financing the Institute's operation. In an environment of extremely high government debt, the only realistic option is to privatise the Company under more flexible terms, including investment insurance and, especially, the completion of the investment cycle.

Table I A summary of revenues and expenditures of the Institute, 2OIO-2OI4 (in million HRK)

\begin{tabular}{lrrrrrr} 
& $\mathbf{2 0 I O}$ & $\mathbf{2 0 I I}$ & $\mathbf{2 0 I 2}$ & $\mathbf{2 0 I 3}$ & $\mathbf{2 0 I 4}$ \\
\hline Total revenues & 91.9 & 93.0 & 66.2 & 48.5 & 20.2 \\
\hline Operating revenues & 90.6 & 92.5 & 65.4 & 46.8 & 17.9 \\
\hline Financial revenues & $\mathrm{I} .3$ & 0.5 & 0.8 & $\mathrm{I} .7$ & 2.3 \\
\hline Total expenditures & 104.5 & 93.0 & 79.5 & 70.1 & 41.3 \\
\hline Operating expenses & 97.7 & 87.6 & 74.0 & 60.5 & 34.9 \\
\hline Financial expenses & 6.8 & 5.4 & 5.5 & 9.7 & 6.4 \\
\hline Net profit/loss for the period & $\mathbf{- I 2 . 6}$ & $\mathbf{0 . 0}$ & $\mathbf{- I 3 . 3}$ & $\mathbf{- 2 I . 7}$ & $\mathbf{- 2 I . I}$ \\
\hline
\end{tabular}

Source: Financial statements of the company Imunološki zavod d.d., 20IO-2OI4.

Table 2 A summary of assets and liabilities of the Institute, 2010-20I4 (in million HRK)

\begin{tabular}{|c|c|c|c|c|c|}
\hline & 2010 & $20 I I$ & 2012 & 2013 & 2014 \\
\hline Fixed assets & I73.2 & I7I.0 & I73.0 & 175.6 & I70.I \\
\hline Tangible assets & I73.2 & I7I.O & I73.0 & I75.6 & I7O.I \\
\hline Fixed financial assets & O.O & O.O & O.O & 0.0 & O.O \\
\hline Current assets & 81.9 & 66.4 & 66.0 & 42.0 & 32.6 \\
\hline Inventories & 44.I & 47.4 & 34.0 & 26.4 & 27.6 \\
\hline Short-term receivables & 17.5 & I6.5 & 26.7 & I2.I & 4.7 \\
\hline Current financial assets & 0.0 & 0.8 & 3.8 & 0.0 & 0.0 \\
\hline Cash at bank and on hand & 20.2 & I.7 & I.6 & 3.4 & 0.3 \\
\hline
\end{tabular}




\begin{tabular}{|c|c|c|c|c|c|}
\hline Total assets & 255.0 & 237.3 & 239.0 & 217.6 & 202.7 \\
\hline Off-balance sheet bills & 4.0 & $\mathrm{n} / \mathrm{a}$ & $\mathrm{n} / \mathrm{a}$ & $\mathrm{n} / \mathrm{a}$ & $\mathrm{n} / \mathrm{a}$ \\
\hline Capital reserves & I42.I & I42.2 & II9.7 & 98.2 & 77.I \\
\hline Subscribed capital & 85.6 & 85.6 & 85.6 & 85.6 & 85.6 \\
\hline Reserves from profit & I.5 & 0.0 & 0.0 & 0.0 & 0.0 \\
\hline Revaluation reserves & 66.7 & 66.3 & 66.3 & 65.6 & 65.6 \\
\hline Retained profit/loss & 0.9 & -9.8 & $-\mathrm{I} 8.9$ & $-3 \mathrm{I} .4$ & -53.1 \\
\hline Profit/loss of the business year & $-\mathrm{I} 2.6$ & 0.0 & $-\mathrm{I} 3.3$ & -21.7 & $-2 I . I$ \\
\hline Provisions & I.O & I.O & I.O & 0.0 & 0.0 \\
\hline Long-term liabilities & 17.9 & 24.7 & 61.3 & 53.9 & 46.7 \\
\hline Short-term liabilities & 94.0 & 69.4 & 57.0 & 65.5 & 78.9 \\
\hline Total liabilities & 255.0 & 237.3 & 239.0 & 217.6 & 202.7 \\
\hline Off-balance sheet bills & 4.0 & 4.0 & 4.5 & 4.6 & 4.6 \\
\hline
\end{tabular}

Source: Financial statements of the company Imunološki zavod d.d., 20IO-2OI4.

Table 3 Employees of the Institute, 20IO-20I4.

\begin{tabular}{lrrrrr} 
& 2010 & $20 I I$ & $20 I 2$ & 2013 & 2014 \\
No. of Management Board members & 2 & I & 2 & 2 & 3 \\
\hline No. of employees & $33 \mathrm{I}$ & $3 \mathrm{I} 7$ & $27 \mathrm{I}$ & $\mathrm{I} 92$ & $\mathrm{I} 67$ \\
\hline Average net salary (in HRK) & 4,869 & $5, \mathrm{OOI}$ & $5, \mathrm{I} 67$ & 5,517 & 5,267 \\
\hline
\end{tabular}

Source: Financial statements of the company Imunološki zavod d.d., 20IO-2OI4.

Table 4 The Institute's liabilities to banks and other financial institutions, 2OIO-2OI4. (in million HRK)

\begin{tabular}{lrrrrrr} 
& $\mathbf{2 0 I O}$ & $\mathbf{2 O I I}$ & $\mathbf{2 0 I 2}$ & $\mathbf{2 0 I 3}$ & $\mathbf{2 0 I 4}$ \\
Short-term & I6.6 & 7.7 & I.9 & 9.5 & I3.7 \\
\hline Long-term & I.3 & 8.1 & 44.8 & 37.5 & 30.3 \\
\hline TOTAL & $\mathbf{I 7 . 8}$ & $\mathbf{I 5 . 8}$ & $\mathbf{4 6 . 7}$ & $\mathbf{4 7 . 0}$ & $\mathbf{4 4 . 0}$ \\
\hline
\end{tabular}

Source: Financial statements of the company Imunološki zavod d.d., 2OIO-2OI4.

Table 5 Financial indicators for the Institute, 20IO-20I4.

\begin{tabular}{|c|c|c|c|c|c|}
\hline & 2010 & $20 I I$ & 2012 & 2013 & 2014 \\
\hline Debt-equity ratio & $0.2 \mathrm{I}$ & 0.29 & 0.72 & 0.63 & 0.55 \\
\hline Total indebtedness & I.3I & I.IO & I. 38 & I.39 & I.47 \\
\hline Current ratio & 0.87 & 0.96 & I.I6 & 0.64 & 0.41 \\
\hline Quick ratio & 0.40 & 0.27 & 0.56 & 0.24 & 0.06 \\
\hline Cash ratio & 0.20 & 0.02 & 0.03 & 0.05 & 0.00 \\
\hline Total asset turnover ratio & 0.36 & 0.39 & 0.27 & $0.2 \mathrm{I}$ & 0.09 \\
\hline Current asset turnover ratio & I.II & I. 39 & 0.99 & I.II & 0.55 \\
\hline Inventory turnover ratio & 2.05 & I.95 & I.92 & I. .77 & 0.65 \\
\hline Receivables turnover ratio & 5.17 & $5.6 \mathrm{I}$ & 2.45 & 3.86 & 3.78 \\
\hline Gross profit margin & -0.06 & 0.06 & -0.12 & -0.26 & -0.82 \\
\hline Net profit margin & -0.14 & 0.00 & -0.20 & -0.46 & -I.I8 \\
\hline Total assets profitability & -0.02 & 0.02 & -0.03 & -0.06 & -0.07 \\
\hline Equity profitability & -0.07 & 0.06 & -0.09 & -0.14 & -0.17 \\
\hline Average collection period & 70 & 64 & I47 & 93 & 95 \\
\hline Average settlement period & 357 & 223 & 326 & 337 & I.O50 \\
\hline
\end{tabular}

Source: Financial statements of the company Imunološki zavod d.d., 2OIO-2OI4.

Table 6 Operating expenses of the Institute, 20IO-20I4 (in million HRK)

\begin{tabular}{lrrrrrr} 
& $\mathbf{2 0 I O}$ & $\mathbf{2 O I I}$ & $\mathbf{2 0 I 2}$ & $\mathbf{2 0 I 3}$ & $\mathbf{2 0 I 4}$ \\
Operating expenses & $\mathbf{9 7 . 7}$ & $\mathbf{8 7 . 6}$ & $\mathbf{7 4 . 0}$ & $\mathbf{6 0 . 5}$ & $\mathbf{3 4 . 9}$ \\
\hline Change in the value of inventories & -2.7 & -4.3 & 3.3 & - I.9 & 0.9 \\
\hline Material expenses & $49 . \mathrm{I}$ & 49.0 & $\mathbf{2 5 . 3}$ & $\mathbf{2 3 . 7}$ & 9.6 \\
\hline Staff expenses & 32.6 & $3 \mathrm{I} .4$ & $\mathbf{2 7 . 7}$ & $\mathbf{2 0 . 8}$ & I7.3 \\
\hline Depreciation charges & 3.2 & $3 . \mathrm{I}$ & 3.0 & 3.0 & 2.8 \\
\hline Other expenses & 7.8 & 7.6 & I4.I & 5.6 & 3.6 \\
\hline Value adjustment & 6.7 & O.7 & O.6 & 9.3 & 0.8 \\
\hline Provisions & I.O & O.O & O.O & O.I & O.O \\
\hline
\end{tabular}

Source: Financial statements of the company Imunološki zavod d.d., 20IO-20I4. 